DOI: https://doi.org/10.31933/dijms.v3i3 Received: 12 November 2021, Revised: 25 December 2021, Publish: 15 January 2022

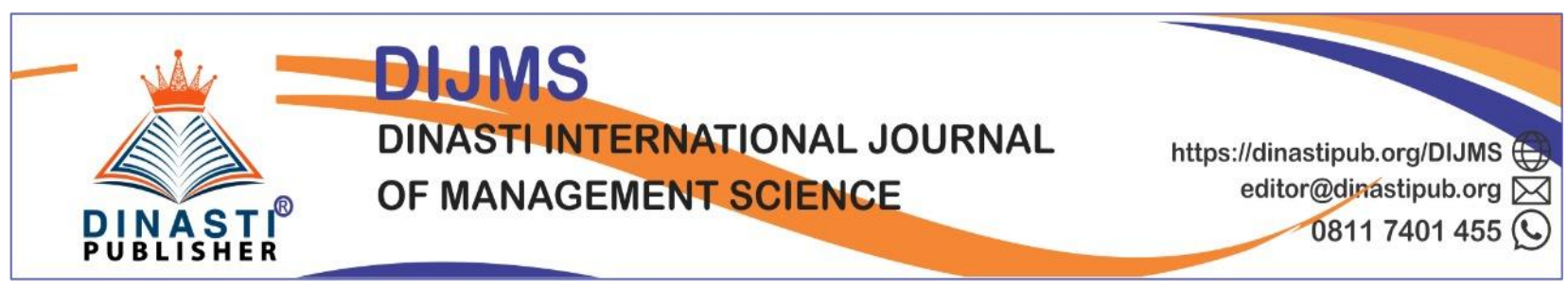

\title{
EMPLOYEE PERFORMANCE MODEL: WORK ENGAGEMENT THROUGH JOB SATISFACTION AND ORGANIZATIONAL COMMITMENT (A STUDY OF HUMAN RESOURCE MANAGEMENT LITERATURE STUDY)
}

\author{
Andri Yandi' ${ }^{1}$, Hazimi Bimaruci Hazrati Havidz \\ ${ }^{1)}$ Lecture of Economics Faculty, Universitas Batanghari Jambi, email: andri.yandi@unbari.ac.id \\ ${ }^{2)} \mathrm{Ph} . \mathrm{D}$ Student, Wuhan University of Technology, 205 Luoshi road, Wuhan, Hbei, China, email: \\ hazimi.bimaruci@gmail.com
}

Corresponding Author: Andri Yandi

\begin{abstract}
Previous research or relevant research is very important in a research or scientific article. Previous research or relevant research serves to strengthen the theory and phenomena of the relationship or influence between variables. This article reviews the factors that influence employee performance, namely: job involvement through job satisfaction and organizational commitment, a study of Human Resource Management literature. The purpose of writing this article is to build a hypothesis of the influence between variables to be used in further research. The results of this literature review article are: 1) job involvement (X) has an effect on employee job satisfaction $\left(\mathrm{M}_{1}\right)$; 2) work involvement $(\mathrm{X})$ has an effect on organizational commitment $\left(\mathrm{M}_{2}\right)$; 3) work involvement $(\mathrm{X})$ affects employee performance $(\mathrm{Y})$; 4) job satisfaction $\left(\mathrm{M}_{1}\right)$ has an effect on employee performance $(\mathrm{Y}) ; 5)$ organizational commitment $\left(\mathrm{M}_{2}\right)$ has an effect on employee performance $(\mathrm{Y}) ; 6)$ work involvement $(\mathrm{X})$ through job satisfaction $\left(\mathrm{M}_{1}\right)$ has an effect on employee performance (Y); and 7) work involvement $(\mathrm{X})$ through organizational commitment $\left(\mathrm{M}_{2}\right)$ has an effect on employee performance $(\mathrm{Y})$.
\end{abstract}

Keyword: Job Engagement, Job Satisfaction, Organizational Commitment, and Performance.

\section{INTRODUCTION}

Every organization has a goal to achieve optimal performance. These goals are different from each other, some are in the form of profit, social services, education improvement, career development and so on. Management of a good organization can be realized if the goals of the organization have been achieved. The purpose of the organization is part of the implementation of organizational functions, namely placing the right employees in the right positions. Even though an organization from the time of recruitment to placement of employees has been selective, in reality there are still unwanted problems when carrying out operations that can 
hinder employee performance. Therefore the company must look at the work involvement of each employee to place him in a position in order to produce a maximum level of performance so that all work can be completed properly.

Employee engagement is critical to the company's long-term growth and increasing profitability in an increasingly competitive industry. In recent years, the increasingly fierce industry competition has resulted in many companies needing to restructure their strategies to increase their existence. Employees in a company are not only a part of carrying out company functions, but also become valuable assets in the company's success. In order to realize the success of the company, the company's valuable assets, namely employees, need to have full involvement in the company. Companies must also encourage the creation of employee involvement in their work so as to improve company performance. Dicke, Holwerda, \& Kontakos in (Rani et al., 2020) revealed that employees with high work involvement will show positive behavior during work so that company goals and success can be achieved. Moreover, work engagement can also be considered as a participatory process that uses the entire capacity of workers and is designed to increase commitment to the success of an organization.

Company failure can be seen from the decrease in employee involvement which can be seen from the low behavior of employees in a company such as being lazy at work, often being late at work, not obeying company rules and lack of concern for work and colleagues. This is in accordance with the research of (Kembau et al., 2018) which suggests that employees who are not involved in their work will show a lack of caring attitude towards work, namely only carrying out work according to orders, not focusing on work, relaxing at work, not taking advantage of work time to maximize work, thus leading to a decrease in employee productivity and a decrease in company income.

This study links job involvement to employee performance through job satisfaction and organizational commitment. Based on the background, the problems to be discussed can be formulated in order to build hypotheses for further research, namely:

1) Does work involvement affect employee job satisfaction?

2) Does work involvement affect organizational commitment?

3) Does work involvement affect performance?

4) Does job satisfaction affect performance?

5) Does organizational commitment affect performance?

6) Does job involvement through job satisfaction affect performance?

7) Does work involvement through organizational commitment affect performance?

\section{LITERATURE REVIEW}

Employee Performance (Y)

Colquitt et al, (2011) stated that performance is the value of a series of worker behaviors that contribute, either positively or negatively, to the completion of organizational goals. Another opinion states that performance is the result of work related to organizational goals such as quality, efficiency and other performance of effectiveness (Gibson, Ivancevich, 2010).

Rogelberg (2007), has defined the performance of activities that are usually part of the work and activities of individuals and must do so. In theory, there are many factors that can affect performance, according to (Anwar Prabu, 2017) stating that the factors that can affect performance are:

a) The ability factor (ability. Psychologically, the ability of employees consists of potential ability (IQ) and reality ability (knowledge + skill). This means that employees who have an 
IQ above the average (IQ 110-120) with good education adequate for his position and skilled in carrying out daily work, it will be easier for him to achieve the expected performance.Therefore, employees need to be placed in jobs that match their expertise.

b) Motivation factor. Motivation is formed from the attitude of an employee in dealing with work situations. Motivation is a condition that moves employees who are directed to achieve organizational goals (work goals). Mental attitude is a mental condition that encourages employees to try to achieve maximum work performance. The mental attitude of the employee must be a psychophysical mental attitude (mentally, physically, objectively, and situationally ready), meaning that an employee must be mentally prepared, physically capable, physically understand, understand the main goals of the work targets to be achieved, be able to utilize, and create work situations.

Based on the theories that have been stated above, the writer finally concludes that the factors that influence individual performance in the organization can be sourced from the environment (including the organization) as well as factors that come from within the employees themselves. Environmental factors are factors related to the organization, such as leadership support, work environment, Perceived organizational support, compensation, communication, organizational culture, performance appraisal and so on. While the factors that come from the employees themselves (individuals) are those related to the character, behavior and personal qualifications of the employees which are implemented in the form of job satisfaction, motivation, organizational commitment, loyalty, work discipline, and so on. The factors that affect employee performance are described as follows:

\begin{tabular}{|l|l|l|}
\hline \multicolumn{1}{|c|}{ Environmental factor } \\
1. Leadership & \multicolumn{1}{|c|}{ Faktor Individu } \\
2. Work Environment & 1. Job Satisfaction \\
3. Organizational Culture & 2. Motivation \\
4. Work Engagement & 3. Organizational \\
5. Perceived organizational support & Commitment \\
6. Compensation & 4. Loyalty \\
7. Communication & 5. Work Discipline \\
8. And others. & 6. And others. \\
\hline
\end{tabular}

Figure 1: Factors Affecting Performance

According to Mitchel in (Sedarmayanti, 2017) employee performance can be measured through: 1) Quality of work; 2) Promptness (Timeliness); 3) Initiative (initiative in completing tasks); 4) Capability (Ability to complete tasks); and 5) Communication (Ability to cooperate with other parties).

Then according to Werther and Davis (2010) employee performance appraisal in an organization can be measured through the following indicators:

a) Performance improvement, which allows employees and managers to take actions related to improving performance.

b) Compensation adjustment, namely helping decision makers to determine who is entitled to receive a salary increase or vice versa.

c) Placement decisions, namely determining promotions, transfers, and demotions. 
d) Training and development needs, namely evaluating the development needs of employees so that their performance is more optimal.

e) Career planning and development, namely guiding to determine the type of career and the potential that can be achieved.

f) Staffing process deficiencies that affect employee recruitment procedures.

g) Informational inaccuracies and job-design errors, namely helping to explain what errors have occurred in human resource management, especially in the fields of job-analysis, jobdesign, and human resource management information systems.

h) Equal employment opportunity, namely showing that the placement decision is not discriminatory.

i) External challenges. Sometimes employee performance is influenced by external factors such as family, personal finances, health, and others. Usually these factors are not very visible, but by conducting a performance appraisal, these external factors will be visible so that it helps the human resources department to provide assistance for improving employee performance.

j) Feedback. Provide feedback for personnel matters as well as for employees.

Based on the description above, it can be synthesized that employee performance is the overall result of the work they do and the level of success achieved by employees in their field of work which can be directly reflected in the output produced, both in terms of quantity and quality, according to the criteria applied to the job. Which can be measured through the following indicators: 1) Quality of work; 2) Quantity of work; 3) Job knowledge; 4) Attitude; 5) Communications; and 6) Initiatives.

Employee performance has been widely studied by previous researchers including: (Ali et al., 2016), (Prihartono \& Ali, 2020), (Harini et al., 2020), (Riyanto, Pratomo, et al., 2017), (Brata, Husani, Hapzi, 2017), (Agussalim, Kristin, et al., 2016), (Desfiandi et al., 2017), (Sulaeman et al., 2019), (Djojo \& Ali, 2012), (Riyanto, Sutrisno, et al., 2017), (Prayetno \& Ali, 2017), (Ridwan et al., 2020), (Djoko Setyo Widodo, P. Eddy Sanusi Silitonga, 2017), (Agussalim, Ayu Rezkiana Putri, et al., 2016).

\section{Work Engagement $(X)$}

Job involvement is the degree to which employees identify with their work, actively participate in their work, and perceive their performance at work as more important for their own good. Employees with high levels of job involvement strongly recognize and care about the type of work they do. High rates have been found to be associated with lower absenteeism and lower employee turnover rates (Coulter \& Robbins, 2012). According to (Kreitner \& Kinicki, 2014) said that work involvement is the degree to which a person consciously feels bound and unbound and concerned with the work being done.

(Hiryappa, 2009) defines job involvement as the degree to which individuals identify with their work, actively participate in it, and consider their performance to be important for their selfworth. A high level of work involvement will reduce the rate of absenteeism and resignation of employees in an organization. Meanwhile, a low level of work involvement will increase absenteeism and higher resignation rates in an organization.

Work involvement according to Kenungo in (Abutayeh \& Al-Qatawneh, 2012) is the main attitude that refers to the psychological identification by an employee of his job, where employees feel that work is representative of their life and many of their interests and life goals are related to their work. According to Muchinsky in (Paryati et al., 2019) job involvement refers 
to the degree to which a person identifies psychologically with his or her work and the importance of work to one's self-image.

From some of the theories that have been put forward above, it can be concluded that work involvement is employee participation which is reflected in the form of work dedication that is more concerned with the organization than personal interests. Employees who feel involved in the organization have a high concern for the organization.

According to (S. Robbins \& Judge, 2013) Job involvement can be measured by several indicators including: a person's activeness in his work, a sense of siding with work, and considers work important as self-esteem. The indicators used in measuring job involvement according to (Luthans, 2006) are:

a) Actively participate in work

Actively participating in work can indicate a worker is involved in work. Active participation is someone's attention to something. From this level of attention, it can be seen how much an employee cares, cares, and masters the area of concern.

b) Showing work as a priority

Shows work as the main thing for employees who can represent the level of work involvement. What if employees feel that their work is the main thing. An employee who prioritizes work will try his best for his work and considers his work as an interesting center in life and that deserves to be prioritized.

c) Sees work as important to self-esteem.

Job involvement can be seen from the attitude of a worker in thinking about his work, where an employee considers work important for his self-esteem. Self-esteem is a guide to self-confidence and self-respect, having strong self-esteem means feeling comfortable with life and full of confidence, namely having competence and being able to overcome life's problems. Self-esteem is a sense of likes and dislikes about oneself. If the work is felt to be meaningful and very valuable both materially and psychologically to the worker, the worker appreciates and will carry out the work as well as possible so that work involvement can be achieved, and the employee feels that their work is important for his self-esteem.

\section{Job satisfaction (M1)}

Job satisfaction is an emotional attitude that is pleasant and loves his job. This attitude is reflected by work morale, discipline and work performance. Job satisfaction is enjoyed on the job, outside of work, and a combination of inside and outside work (Hasibuan, 2016). (S. Robbins \& Judge, 2013) said: "Job satisfaction is a general attitude towards a person's job, the difference between the amount of remuneration an employee receives and the amount they believe they should receive." (Handoko, 2011) argued that job satisfaction is a favorable or unfavorable emotional state in which employees view their work. Job satisfaction reflects a person's feelings towards his job.

Job satisfaction is measured through the Summedationscore method (SCM) model parameter which takes the indicator (S. Robbins \& Judge, 2013) includes the following indicators:

a) Good relations in the work environment, namely the existence of a supervisory relationship, social relations among employees, and the ability to adapt to work facilities. This is shown through the attitude or behavior of employees who show the ability to complete work tasks even without supervision, the willingness to foster communication 
with work relations, can work together to complete certain tasks in a work team or individually, and the willingness to take good care of work facilities or equipment.

b) Utility abilities, namely abilities related to employee attitudes towards leadership policies, working hours regulatory policies, opportunities for creativity and career promotion opportunities. This attitude of employees will be shown through acceptance of leadership policies, attitudes to comply with the rules of working hours that have been set, opportunities to develop work creativity and a desire to take advantage of opportunities to increase career paths.

c) Welfare policies, namely policies that have an effect on employee satisfaction on the system of wages, allowances/compensation, and incentives. The welfare policy is measured by employees' perceptions of the wage system, the amount of take home pay received compared to the workload, the system of providing benefits, as well as the incentive system and overtime pay.

d) The company's attention to work security issues is related to the level of work risk, occupational health and safety, and facilities that support K3. This can be measured by the ability or willingness of employees to overcome all risks arising from work, employees receive guarantees for occupational health and safety in the form of benefits or occupational health and safety insurance, and in the work process employees obtain security rights in the form of complete personal protective equipment. adequate.

\section{Organizational Commitment $\left(\mathbf{M}_{2}\right)$}

Organizational commitment is the identification and involvement of a person who is relatively strong in the organization. Organizational commitment is the desire of organizational members to maintain membership in the organization and are willing to strive for the achievement of organizational goals. The following will present the definition of organizational commitment according to experts.

Allen and Meyer in (Kreitner \& Kinicki, 2014) define organizational commitment as a concept that has three dimensions, namely affective, normative and continuance commitment. Affective commitment is the degree to which an employee is emotionally attached to, knows and is involved in the organization. Continuance commitment is an assessment of the costs associated with leaving the organization. Normative commitment refers to the degree to which a person is psychologically bound to become an employee of an organization based on feelings such as loyalty, affection, warmth, ownership, pride, pleasure, happiness and others.

According to (Sopiah, 2015) defines organizational commitment as an employee's psychological bond in the organization which is characterized by a strong belief and acceptance of the goals and values of the organization, a willingness to strive for the achievement of organizational interests and a strong desire to maintain position as a member of the organization.

According to (Triatna, 2015) organizational commitment is a level of employee loyalty to the organization/company which is characterized by their desire to remain part of the organization, do their best for the organization, and always maintain the good name of the organization.

Based on the study of the definitions above, the authors try to define organizational commitment, namely a level of loyalty of organizational members to the organization where they belong which is characterized by a strong belief and acceptance of the goals and values of the organization to remain loyal to be part of the organization, act the best for the organization in achieving organizational goals. 
Meyer, Allen and Smith in (Sopiah, 2015) describe the forms of organizational commitment and the factors that shape them as follows:

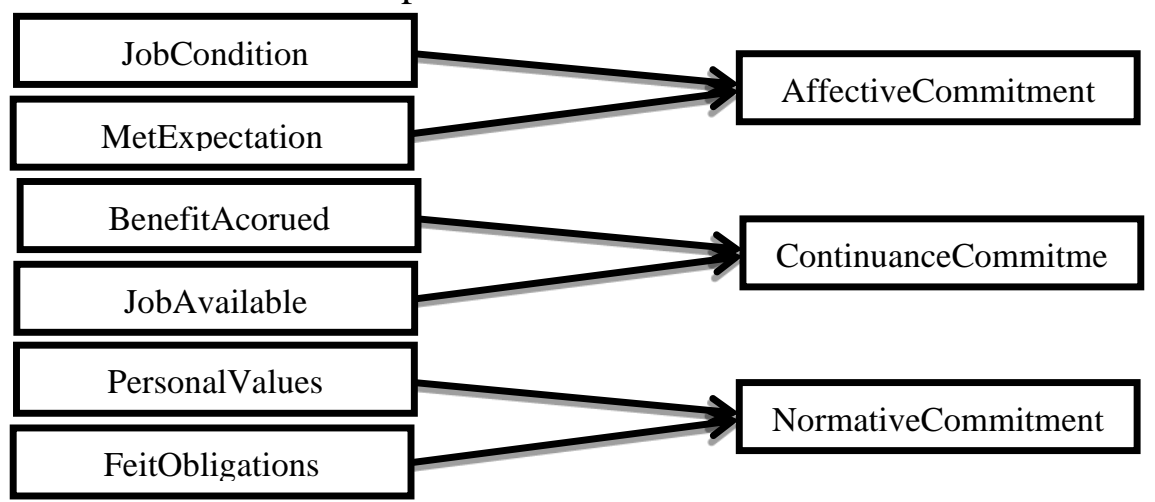

Description: $\rightarrow$ meaningful as a forming factor.

Figure 2: Factors forming organizational commitment

a) Affective commitment, occurs when employees want to be part of the organization because of an emotional bond.

b) Continuance commitment, arises when employees remain in an organization because they need a salary and other benefits, or because the employee cannot find another job.

c) Normative commitment, arising from the values in employees. Employees remain members of the organization because of the awareness that commitment to the organization is something that should be done.

Table 1: Previous Research

\begin{tabular}{|c|c|c|c|c|}
\hline No & $\begin{array}{l}\text { Name and } \\
\text { Year }\end{array}$ & Previous Research Results & $\begin{array}{c}\text { Similarities to this } \\
\text { article }\end{array}$ & Difference with this article \\
\hline 1 & $\begin{array}{l}\text { (Tanjung, } \\
2019)\end{array}$ & $\begin{array}{l}\text { The results of this study indicate } \\
\text { that job involvement and job } \\
\text { satisfaction have an effect on } \\
\text { employee organizational } \\
\text { commitment, either partially or } \\
\text { simultaneously }\end{array}$ & $\begin{array}{lr}\begin{array}{l}\text { Together, } \\
\text { examine }\end{array} & \text { we } \\
\text { engagement } & \text { on } \\
\text { organizational } \\
\text { commitment }\end{array}$ & $\begin{array}{l}\text { This study uses two } \\
\text { independent variables, namely } \\
\text { job involvement and job } \\
\text { satisfaction on organizational } \\
\text { commitment. Meanwhile, in } \\
\text { this study, job satisfaction and } \\
\text { organizational commitment } \\
\text { were used as intervening } \\
\text { variables. }\end{array}$ \\
\hline 2 & $\begin{array}{l}\text { (Rikmaratri \& } \\
\text { Prohimi, 2018) }\end{array}$ & $\begin{array}{l}\text { The results showed that partially } \\
\text { work involvement had no effect } \\
\text { on organizational commitment, } \\
\text { while organizational support had } \\
\text { a significant effect on } \\
\text { organizational commitment }\end{array}$ & $\begin{array}{lr}\text { Together, } & \text { we } \\
\text { examine } & \text { work } \\
\text { engagement } & \text { on } \\
\text { organizational } \\
\text { commitment }\end{array}$ & $\begin{array}{l}\text { This study uses two } \\
\text { independent variables, namely } \\
\text { work involvement and } \\
\text { organizational support for } \\
\text { organizational commitment. } \\
\text { Meanwhile, in this study, } \\
\text { organizational commitment is } \\
\text { used as an intervening } \\
\text { variable that mediates } \\
\text { performance. }\end{array}$ \\
\hline
\end{tabular}




\begin{tabular}{|c|c|c|c|c|}
\hline 3 & $\begin{array}{l}\text { (Syamsuri, } \\
2018 \text { ) }\end{array}$ & $\begin{array}{l}\text { The results of the analysis show } \\
\text { that the kaizen culture has no } \\
\text { effect on organizational } \\
\text { commitment, but has an effect } \\
\text { on employee performance. } \\
\text { Furthermore, work involvement } \\
\text { has an effect on organizational } \\
\text { commitment and employee } \\
\text { performance. }\end{array}$ & $\begin{array}{l}\text { Both review work } \\
\text { engagement } \\
\text { through } \\
\text { organizational } \\
\text { commitment. }\end{array}$ & $\begin{array}{l}\text { In this study, the researcher } \\
\text { used two independent } \\
\text { variables and one intervening } \\
\text { variable, while this article } \\
\text { itself used one independent } \\
\text { variable and two intervening } \\
\text { variables, namely job } \\
\text { satisfaction and organizational } \\
\text { commitment. }\end{array}$ \\
\hline 4 & $\begin{array}{l}\text { (Septiadi et al., } \\
\text { 2017) }\end{array}$ & $\begin{array}{l}\text { The results of this study } \\
\text { conclude that work involvement } \\
\text { has an influence on employee } \\
\text { performance, either directly or } \\
\text { indirectly through } \\
\text { organizational commitment. }\end{array}$ & $\begin{array}{l}\text { Both review work } \\
\text { engagement } \\
\text { through } \\
\text { organizational } \\
\text { commitment to } \\
\text { performance. }\end{array}$ & $\begin{array}{l}\text { In this study, the researcher } \\
\text { used one intervening variable, } \\
\text { while this article itself uses } \\
\text { two intervening variables, } \\
\text { namely job satisfaction and } \\
\text { organizational commitment. }\end{array}$ \\
\hline 5 & $\begin{array}{l}\text { (Munparidi \& } \\
\text { Sayuti, 2020) }\end{array}$ & $\begin{array}{l}\text { The results of this study explain } \\
\text { that job involvement has no } \\
\text { effect on job satisfaction and } \\
\text { employee performance, only job } \\
\text { satisfaction has an influence on } \\
\text { employee performance }\end{array}$ & $\begin{array}{lr}\text { They both } & \text { study } \\
\text { job involvement } \\
\text { through } & \text { job } \\
\text { satisfaction } & \text { on } \\
\text { performance. } & \end{array}$ & $\begin{array}{l}\text { In this study, the researcher } \\
\text { used one intervening variable, } \\
\text { while this article itself uses } \\
\text { two intervening variables, } \\
\text { namely job satisfaction and } \\
\text { organizational commitment. }\end{array}$ \\
\hline 6 & $\begin{array}{l}\text { (Kembau et al., } \\
\text { 2018) }\end{array}$ & $\begin{array}{l}\text { The results of this study } \\
\text { conclude that job involvement } \\
\text { and competence have an } \\
\text { influence on teacher satisfaction } \\
\text { and performance. Likewise, job } \\
\text { satisfaction has an influence on } \\
\text { teacher performance. }\end{array}$ & $\begin{array}{lr}\text { They both } & \text { study } \\
\text { job involvement } \\
\text { through } & \text { job } \\
\text { satisfaction } & \text { on } \\
\text { performance. } & \end{array}$ & $\begin{array}{l}\text { In this study, the researcher } \\
\text { used two independent } \\
\text { variables and one intervening } \\
\text { variable, while this article } \\
\text { itself used one independent } \\
\text { variable and two intervening } \\
\text { variables, namely job } \\
\text { satisfaction and organizational } \\
\text { commitment. }\end{array}$ \\
\hline 7 & $\begin{array}{l}\text { (Paryati et al., } \\
\text { 2019) }\end{array}$ & $\begin{array}{l}\text { The results of this study } \\
\text { conclude that work involvement } \\
\text { has an influence on } \\
\text { organizational commitment and } \\
\text { employee performance. } \\
\text { Likewise, organizational } \\
\text { commitment has an influence on } \\
\text { employee performance. }\end{array}$ & $\begin{array}{l}\text { Both review work } \\
\text { engagement } \\
\text { through } \\
\text { organizational } \\
\text { commitment to } \\
\text { performance. }\end{array}$ & $\begin{array}{l}\text { In this study, the researcher } \\
\text { used one intervening variable, } \\
\text { while this article itself uses } \\
\text { two intervening variables, } \\
\text { namely job satisfaction and } \\
\text { organizational commitment. }\end{array}$ \\
\hline 8 & $\begin{array}{l}\text { (Logahan \& } \\
\text { Aesaria, 2014) }\end{array}$ & $\begin{array}{l}\text { The results of this study } \\
\text { conclude that organizational } \\
\text { culture has no effect on } \\
\text { organizational commitment, but } \\
\text { does affect employee } \\
\text { performance. While work } \\
\text { involvement has an influence on } \\
\text { organizational commitment and } \\
\text { employee performance. }\end{array}$ & $\begin{array}{l}\text { Both review work } \\
\text { engagement } \\
\text { through } \\
\text { organizational } \\
\text { commitment to } \\
\text { performance. }\end{array}$ & $\begin{array}{l}\text { In this study, the researcher } \\
\text { used one intervening variable, } \\
\text { while this article itself uses } \\
\text { two intervening variables, } \\
\text { namely job satisfaction and } \\
\text { organizational commitment. }\end{array}$ \\
\hline
\end{tabular}




\begin{tabular}{|c|c|c|c|c|}
\hline 9 & $\begin{array}{l}\text { Ariana \& } \\
\text { Riana, 2016) }\end{array}$ & $\begin{array}{l}\text { The results of this study prove } \\
\text { that there is a negative effect of } \\
\text { work family conflict and work } \\
\text { stress on employee job } \\
\text { satisfaction. In addition, this } \\
\text { study also proves that there is a } \\
\text { positive influence between job } \\
\text { involvement on job satisfaction, } \\
\text { meaning that if employee job } \\
\text { involvement is high, then the } \\
\text { level of employee job } \\
\text { satisfaction will increase. }\end{array}$ & $\begin{array}{l}\text { Together, we study } \\
\text { work engagement } \\
\text { on job satisfaction }\end{array}$ & $\begin{array}{l}\text { In this study the researchers } \\
\text { used three independent } \\
\text { variables, while this article } \\
\text { itself uses one independent } \\
\text { variable using two intervening } \\
\text { variables, namely job } \\
\text { satisfaction and organizational } \\
\text { commitment. }\end{array}$ \\
\hline 10 & $\begin{array}{l}\text { (Ibrahim et al., } \\
\text { 2021) }\end{array}$ & $\begin{array}{l}\text { The results of this study indicate } \\
\text { that work family conflict has no } \\
\text { effect on job satisfaction. While } \\
\text { work involvement has an } \\
\text { influence on job satisfaction. } \\
\text { Furthermore, from the indirect } \\
\text { effect, it was found that work } \\
\text { family conflict and involvement } \\
\text { had an influence on } \\
\text { performance through job } \\
\text { satisfaction. }\end{array}$ & $\begin{array}{lr}\text { They both study } \\
\text { job involvement } \\
\text { through } r \text { job } \\
\text { satisfaction } & \text { on } \\
\text { performance. } & \end{array}$ & $\begin{array}{l}\text { In this study, the researcher } \\
\text { used two independent } \\
\text { variables and one intervening } \\
\text { variable, while this article } \\
\text { itself used one independent } \\
\text { variable and two intervening } \\
\text { variables, namely job } \\
\text { satisfaction and organizational } \\
\text { commitment. }\end{array}$ \\
\hline 11 & $\begin{array}{l}\text { (Sajdah \& } \\
\text { Lukiyana, } \\
\text { 2018) }\end{array}$ & $\begin{array}{l}\text { The results of this study } \\
\text { conclude that work involvement } \\
\text { and organizational support have } \\
\text { an influence on employee } \\
\text { performance either directly or } \\
\text { indirectly through job } \\
\text { satisfaction as an intervening } \\
\text { variable. }\end{array}$ & $\begin{array}{lr}\text { They both study } \\
\text { job involvement } \\
\text { through } \\
\text { satisfaction job } \\
\text { performance. }\end{array}$ & $\begin{array}{l}\text { In this study, the researcher } \\
\text { used two independent } \\
\text { variables and one intervening } \\
\text { variable, while this article } \\
\text { itself used one independent } \\
\text { variable and two intervening } \\
\text { variables, namely job } \\
\text { satisfaction and organizational } \\
\text { commitment. }\end{array}$ \\
\hline 12 & (Yakup, 2017) & $\begin{array}{l}\text { The results of this study indicate } \\
\text { that work involvement, } \\
\text { organizational culture and work } \\
\text { motivation affect employee job } \\
\text { satisfaction, either partially or } \\
\text { simultaneously. }\end{array}$ & $\begin{array}{l}\text { Together, we study } \\
\text { work engagement } \\
\text { on job satisfaction }\end{array}$ & $\begin{array}{l}\text { In this study the researchers } \\
\text { used three independent } \\
\text { variables, while this article } \\
\text { itself uses one independent } \\
\text { variable using two intervening } \\
\text { variables, namely job } \\
\text { satisfaction and organizational } \\
\text { commitment. }\end{array}$ \\
\hline 13 & $\begin{array}{l}\text { (Wuarlima et } \\
\text { al., 2019) }\end{array}$ & $\begin{array}{l}\text { The results showed that } \\
\text { simultaneously and partially, } \\
\text { work-life balance, work } \\
\text { involvement and career } \\
\text { development had an effect on } \\
\text { employee job satisfaction. }\end{array}$ & $\begin{array}{l}\text { Together, we study } \\
\text { work engagement } \\
\text { on job satisfaction }\end{array}$ & $\begin{array}{l}\text { In this study the researchers } \\
\text { used three independent } \\
\text { variables, while this article } \\
\text { itself uses one independent } \\
\text { variable using two intervening } \\
\text { variables, namely job } \\
\text { satisfaction and organizational } \\
\text { commitment. }\end{array}$ \\
\hline 14 & $\begin{array}{l}\text { (Rani et al., } \\
2020)\end{array}$ & $\begin{array}{l}\text { The results of the study show } \\
\text { that there is a positive and } \\
\text { significant relationship between } \\
\text { work involvement and } \\
\text { organizational commitment }\end{array}$ & $\begin{array}{lr}\text { Together, } & \text { we } \\
\text { examine } & \text { work } \\
\text { engagement } & \text { on } \\
\text { organizational } & \\
\text { commitment } & \end{array}$ & $\begin{array}{l}\text { This study only uses two } \\
\text { variables, while this article } \\
\text { uses } 4 \text { variables, two of which } \\
\text { are intervening variables (job } \\
\text { satisfaction and organizational } \\
\text { commitment) to determine the } \\
\text { indirect effect. }\end{array}$ \\
\hline
\end{tabular}




\begin{tabular}{|c|c|c|c|c|}
\hline 15 & $\begin{array}{l}\text { (Rameshkumar, } \\
\text { 2020) }\end{array}$ & $\begin{array}{l}\text { This study confirms that } \\
\text { employee engagement is } \\
\text { positively related to the } \\
\text { affective and normative } \\
\text { components, while job } \\
\text { involvement is not significantly } \\
\text { related to the sustainability } \\
\text { component of organizational } \\
\text { commitment. }\end{array}$ & $\begin{array}{l}\text { Together, } \\
\text { examine } \\
\text { engagement } \\
\text { organizational } \\
\text { commitment }\end{array}$ & $\begin{array}{l}\text { This study only uses two } \\
\text { variables, while this article } \\
\text { uses } 4 \text { variables, two of which } \\
\text { are intervening variables (job } \\
\text { satisfaction and organizational } \\
\text { commitment) to determine the } \\
\text { indirect effect. }\end{array}$ \\
\hline 16 & $\begin{array}{ll}\text { (Trofimov et } & \text { et } \\
\text { al., 2017) }\end{array}$ & $\begin{array}{l}\text { The results of this study } \\
\text { conclude that there is a strong } \\
\text { relationship between } \\
\text { organizational commitment and } \\
\text { work involvement, meaning that } \\
\text { the stronger employees feel they } \\
\text { are involved in their work, the } \\
\text { higher the level of } \\
\text { organizational commitment they } \\
\text { have. }\end{array}$ & $\begin{array}{l}\text { Together, } \\
\text { examine } \\
\text { engagement } \\
\text { organizational } \\
\text { commitment }\end{array}$ & $\begin{array}{l}\text { This study only uses two } \\
\text { variables, while this article } \\
\text { uses } 4 \text { variables, two of which } \\
\text { are intervening variables (job } \\
\text { satisfaction and organizational } \\
\text { commitment) to determine the } \\
\text { indirect effect. }\end{array}$ \\
\hline 17 & $\begin{array}{l}\text { (van Gelderen } \\
\text { \& Bik, 2016) }\end{array}$ & 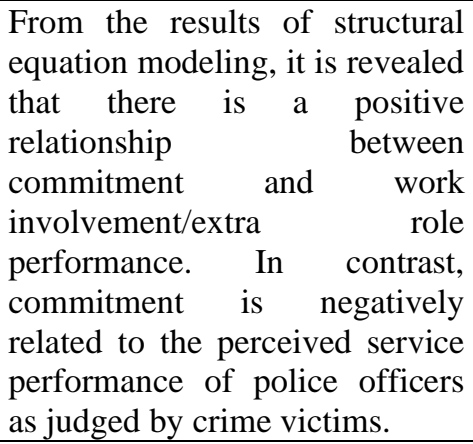 & $\begin{array}{l}\text { Together, } \\
\text { review } \\
\text { engagement } \\
\text { through } \\
\text { organizational } \\
\text { commitment to } \\
\text { performance }\end{array}$ & $\begin{array}{l}\text { In this study, the researcher } \\
\text { used one intervening variable, } \\
\text { while this article itself uses } \\
\text { two intervening variables, } \\
\text { namely job satisfaction and } \\
\text { organizational commitment. }\end{array}$ \\
\hline 18 & $\begin{array}{l}\text { (Nazir \& Islam, } \\
\text { 2017) }\end{array}$ & $\begin{array}{l}\text { The results of this study } \\
\text { conclude that performance is } \\
\text { significantly and positively } \\
\text { influenced by organizational } \\
\text { commitment. This means that if } \\
\text { employees have a high } \\
\text { commitment to the organization } \\
\text { where they take shelter, then the } \\
\text { employee will always be able to } \\
\text { provide optimal work results. }\end{array}$ & $\begin{array}{l}\text { Together reviewing } \\
\text { organizational } \\
\text { commitment to } \\
\text { performance }\end{array}$ & $\begin{array}{l}\text { This study only uses two } \\
\text { variables, namely } \\
\text { commitment and performance, } \\
\text { while this article uses } 4 \\
\text { variables, two of which are } \\
\text { intervening variables (job } \\
\text { satisfaction and organizational } \\
\text { commitment) to determine the } \\
\text { indirect effect of job } \\
\text { involvement on performance. }\end{array}$ \\
\hline 19 & $\begin{array}{ll}\text { Pitaloka } & \& \\
\text { Putri, 2021) } & \end{array}$ & $\begin{array}{l}\text { The results of this study indicate } \\
\text { that work involvement and } \\
\text { organizational commitment } \\
\text { simultaneously have an effect } \\
\text { on performance. While partially } \\
\text { only work involvement has an } \\
\text { influence on performance, while } \\
\text { organizational commitment has } \\
\text { no effect on performance. }\end{array}$ & $\begin{array}{l}\text { Together reviewing } \\
\text { work engagement } \\
\text { and organizational } \\
\text { commitment to } \\
\text { performance }\end{array}$ & $\begin{array}{l}\text { This study uses two } \\
\text { independent variables, namely } \\
\text { work involvement and } \\
\text { organizational commitment to } \\
\text { performance. Meanwhile, in } \\
\text { this study, organizational } \\
\text { commitment is used as an } \\
\text { intervening variable that } \\
\text { mediates performance. }\end{array}$ \\
\hline
\end{tabular}




\section{RESEARCH METHODS}

The method of writing scientific articles is by using qualitative methods and literature review (Library Research). Assessing theory and the relationship or influence between variables from books and journals both offline in the library and online sourced from Mendeley, Scholar Google and other online media.

In qualitative research, literature review must be used consistently with methodological assumptions. This means that it must be used inductively so that it does not direct the questions posed by the researcher. One of the main reasons for conducting qualitative research is that it is exploratory (Hapzi Ali. Nandan Limakrisna, 2013).

\section{FINDINGS AND DISCUSSION}

This article analyzes and discusses the variables of Human Resource Management (HRM), namely: employee performance, job involvement, job satisfaction, and organizational commitment. Where job involvement, job satisfaction, and organizational organizational commitment affect employee performance, previous research and articles relevant to this article include:

\section{1) Job Involvement $(\mathrm{X})$ has an effect on Job Satisfaction (M1)}

Work involvement is one of the internal factors that need to be improved for the progress of the organization so that it can produce maximum work. Job involvement as a participatory process that uses all employee capacities and is designed to encourage increased job satisfaction for the success of an organization. Individuals with a high level of involvement will place work interests at the center of their lives (Yakup, 2017).

According to Dhamayanti, work involvement is one of the variables that has a strong influence on employee job satisfaction. Providing opportunities and trust to employees in completing their work will encourage the creation of employee job satisfaction (Ariana \& Riana, 2016). Furthermore, Dhamayanti in explaining that job involvement is related to how much the individual is involved in his work and considers that his work has a positive impact on himself and a sense of concern for his work. Employees will tend to like and be more satisfied with their jobs if they are given the opportunity to use their skills and abilities as well as freedom and feedback on how well they are doing. (Wuarlima et al., 2019). (Ibrahim et al., 2021), argues that job involvement can foster self-confidence and provide a positive attitude so as to increase employee satisfaction at work.

Several previous studies have proven that work involvement can increase job satisfaction, including research conducted by (Ariana \& Riana, 2016); (Yakup, 2017); (Kembau et al., 2018); (Munparidi \& Sayuti, 2020); and (Hasanah, 2014), where the results of his research reveal that work involvement is able to make employees work well together. Conditions felt by employees to be able to get involved or participate in expressing opinions or ideas within the company. The existence of employee involvement is felt to create a good bond with the company. The significant relationship between job involvement and job satisfaction indicates that they devote more effort and energy to their work because they realize that work can fulfill their needs and therefore experience greater job satisfaction. Based on the findings of previous research, it is expected that employees who are more busy or involved in their work will experience greater job satisfaction (Fung et al., 2014).

Based on this opinion, the company's management needs to further increase the level of employee involvement in order to be able to create employee job satisfaction, this is because the conditions felt by employees to be able to be involved or participate in issuing opinions or ideas in the company will be able to increase the level of employee job satisfaction. Employee involvement is felt because of the emergence of a good bond with the company so that intrinsic satisfaction is fulfilled which is an important condition for work involvement so that employees can work optimally. 


\section{2) Work Involvement $(\mathrm{X})$ has an effect on Organizational Commitment $\left(\mathrm{M}_{2}\right)$}

Job involvement is the degree to which an employee identifies with his work, actively participates in it, and considers his work performance as important in rewarding himself (Coulter \& Robbins, 2012). Employees with high job involvement identify strongly with and care deeply about the type of work they do.

(S. P. Robbins, 1996) argues that job involvement as a participatory process that uses all the capacities of employees and is designed to encourage increased commitment to the success of an organization. Job involvement is the mental and emotional involvement of people in group situations that encourage them to contribute to group goals and share responsibility for achieving those goals.

This is also supported by several studies that have been carried out previously, including research conducted (Rameshkumar, 2020) which confirms that employee engagement is positively related to the affective and normative components, while job involvement is not significantly related to the sustainability component of organizational commitment. This is also stated by Blau and Bloal who argue that high work involvement will cause individuals to be more committed to their organizations, whereas low work involvement will make individuals less committed to their organizations. (Paryati et al., 2019).

In addition (Trofimov et al., 2017) in his research also reveals that there is a strong relationship between organizational commitment and work involvement, meaning that the stronger employees feel they are involved in their work, the higher the level of organizational commitment they have. Then the results of research conducted by (van Gelderen \& Bik, 2016) also suggested that there was a positive relationship between commitment and work involvement.

Then several other studies which also found work involvement had a positive and significant influence on organizational commitment including research conducted by (Tanjung, 2019), (Syamsuri, 2018), (Septiadi et al., 2017), and (Paryati et al., 2019). Where according to Vivian., et al (2019) in their research shows that there is a significant relationship between work involvement and organizational commitment.

\section{3) Work Involvement (X) has an effect on Employee Performance (Y)}

Employee work involvement in a company or organization has a very large role on employee performance. This is because the involvement of employees in a job will make employees identify themselves psychologically with their work, and consider their performance important for themselves and the organization. This means that work involvement will result in the achievement of organizational goals and objectives, where if the employee considers work a necessity he will focus more on his work and will want to be the best for himself, with the assumption of an employee over time employee performance will increase. and organizational goals and objectives will be achieved more quickly (Logahan \& Aesaria, 2014).

This is in line with research conducted by (Septiadi et al., 2017), (Kembau et al., 2018), and (Paryati et al., 2019) which showed that job involvement had a significant positive effect on performance. In addition (Paryati et al., 2019) in his research also suggests that high work involvement will make employee performance better in supporting their work, as well as their ability to think to understand the situation, and carry out their duties with full responsibility in accordance with operating standards and existing deadlines. And they can apply their knowledge and expertise according to their needs as an employee.

\section{4) Job Satisfaction ( $\left.M_{1}\right)$ has an effect on Employee Performance (Y)}

Job satisfaction is a predictor of performance because job satisfaction has a moderate correlation with performance. Satisfied workers are better at fulfilling their obligations as stated 
in the job description. Reality suggests that positive feelings encourage creativity, improve problem solving and decision making, and improve memory and recall certain kinds of information. Positive feelings also improve task persistence and attract more help and support from coworkers (Harini et al., 2020).

Job satisfaction has a moderate positive effect on performance. People who have higher levels of job satisfaction tend to have higher levels of performance, higher levels of citizenship behavior and lower levels of counter-productive behavior Colquit, LePine and Wesson in (Masydzulhak et al., 2016). In addition, several studies conducted by (Wiarah, 2014), (Deswarta, 2017), (Kusumastuti et al., 2019), dan (Silitonga et al., 2017) also suggest that job satisfaction has an influence on performance. If the work is good, then the person will always be able to provide maximum work results for organizational goals.

In addition (Damayanti et al., 2018) in his research also revealed that job satisfaction will be achieved if the needs of employees are met through work. Where job satisfaction is a happy emotional state or positive emotion that comes from evaluating one's work or experience. High job satisfaction will improve employee performance towards the organization where they work.

\section{5) Organizational Commitment (M2) Affects Employee Performance (Y)}

Organizational commitment is seen as a value orientation towards the organization that shows individuals really think about and prioritize their work and organization. Individuals will try to give all the effort they have in order to help the organization achieve its goals. Fink also defines organizational commitment as an attitude that arises from a process called identification that occurs when a person has experience with something, someone, or some idea as an extension of himself. (Nazir \& Islam, 2017).

Organizational commitment is also defined by Allen and Mayer as a form of employee love for their workplace. George and Jones said that employees who are committed to the organization like to be members of the organization, believe in the organization and have good feelings about the organization, and are willing to defend the organization, and want to do something good for the organization (Kreitner \& Kinicki, 2014).

This is in line with research conducted (Nazir \& Islam, 2017) which states that performance is significantly and positively influenced by organizational commitment. This means that if employees have a high commitment to the organization where they take shelter, then the employee will always be able to provide optimal work results. In addition, several studies also reveal that organizational commitment has a positive and significant influence on employee performance, including research conducted by (Hakim, 2015), (Tentama et al., 2019), (S \& Susanto, 2018), (Putranti et al., 2018), and (Samtono, 2019), where the results of his research suggest that high organizational commitment can improve employee performance.

\section{6) Job Involvement (X) through Job Satisfaction $\left(M_{1}\right)$ has an effect on Employee Performance (Y).}

Job involvement is a measure of the extent to which a person is psychologically biased towards his work and considers his performance as a measure of his self-esteem. Employees with high job involvement take sides with the type of work being done and actually the work being done and genuinely care about that type of work. With full involvement in the work, the employee will create good performance and will actively participate in completing the work or task because this is considered important so that employees will feel more satisfied and happy if they can spend most of their time, energy, and thoughts on their work (Hasanah, 2014).

Job involvement is related to how much the individual is involved in his work and perceives that his work has a positive impact on himself and a sense of concern for his work. Employees will tend to like and be more satisfied with their jobs if they are given the opportunity to use their skills and abilities as well as freedom and feedback on how well they are doing. 
Furthermore, the satisfaction obtained by the employee will be implemented in the form of employee participation in expressing opinions or ideas as a reflection of the optimal work results of employees in the organization. Job involvement has an indirect effect on performance through job satisfaction based on research conducted by (Ibrahim et al., 2021); (Sajdah \& Lukiyana, 2018); and (Kembau et al., 2018).

\section{7) Job Involvement (X) through Organizational Commitment $\left(M_{2}\right)$ has an effect on Employee Performance (Y).}

According to Phipps, employee work involvement is an important aspect of organizational life and is considered the key to increasing organizational effectiveness. Furthermore, Dicke, Holwerda, \& Kontakos revealed that employees with high work involvement will show positive behavior during work so that company goals and success can be achieved. Moreover, work engagement can also be considered as a participatory process that uses the entire capacity of workers and is designed to increase commitment to the success of an organization (Rani et al., 2020).

In addition, according to Robbins, the process of work involvement that uses all the capacities of workers will encourage commitment to achieving organizational goals. Human resources who have a high commitment will create positive vibrations between employees and the organization, so that they can help achieve the best performance towards organizational goals and can be developed further (Pitaloka \& Putri, 2021).

Research conducted by Ekmekçi (2011) proves that job involvement has a positive effect on performance through organizational commitment. (Septiadi et al., 2017) stated that work involvement has a positive effect on organizational performance and commitment as a partial mediator. (Paryati et al., 2019) revealed the influence of work involvement and on employee performance to partially mediated organizational commitment as a mediator variable. (Logahan \& Aesaria, 2014) explains that work involvement has an effect on employee performance which is partially mediated by organizational commitment.

\section{Conceptual Framework}

Based on the formulation of the problem, theoretical studies, relevant previous research and discussion of the influence between variables, the framework for thinking in this article is as follows.

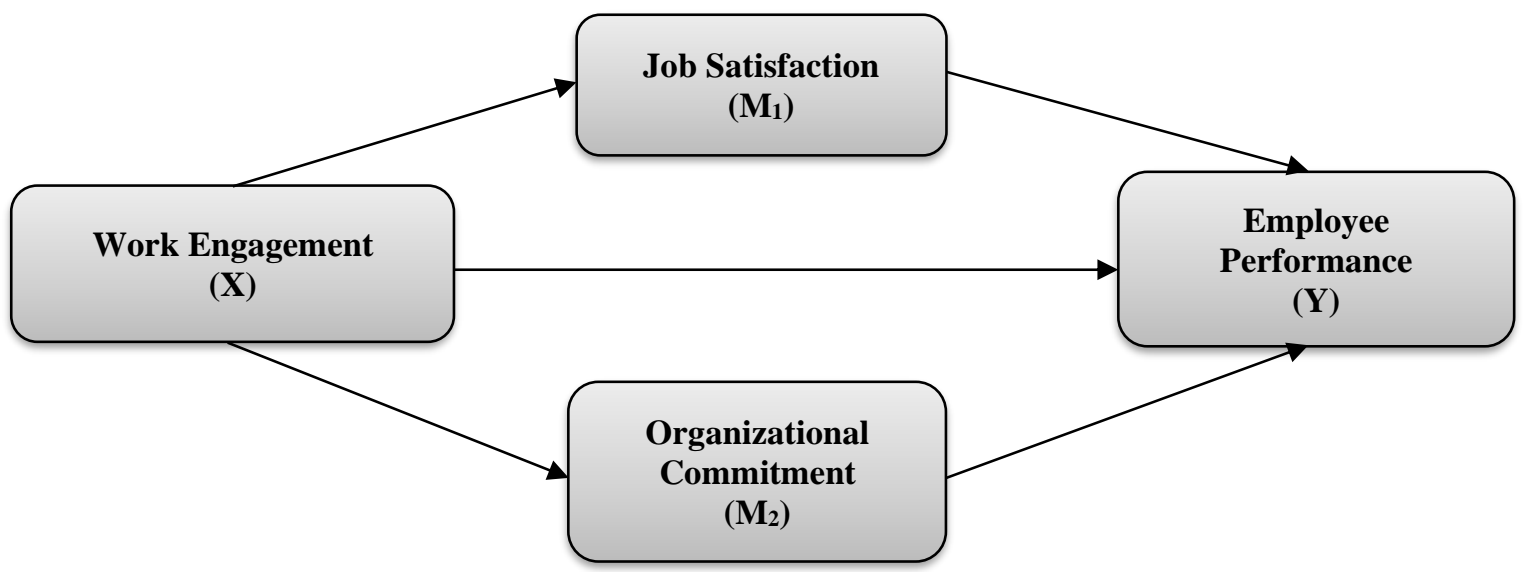

Figure 3: Conceptual Framework

Based on the conceptual framework picture above, then: Job Involvement (X), Job Satisfaction $\left(\mathrm{M}_{1}\right)$ and Organizational Commitment $\left(\mathrm{M}_{2}\right)$ affect Employee Performance (Y). 
Apart from these three exogenous variables that affect employee performance (Y), there are many other variables that influence it, including:

1) Work environment: (Purba et al., 2017) and (Sardjijo \& Ali, 2017);

2) Work Motivation: (Riyanto, Sutrisno, et al., 2017), (Bastari et al., 2020), (Prayetno \& Ali, 2017), (Rivai et al., 2017), (Chauhan et al., 2019).

3) Work Culture: (Harini et al., 2020), (Elmi et al., 2016).

4) Leadership: (Riyanto, Pratomo, et al., 2017), (Purba et al., 2017), (Ridwan et al., 2020), (Djoko Setyo Widodo, P. Eddy Sanusi Silitonga, 2017), (Agussalim, Ayu Rezkiana Putri, et al., 2016).

5) Perception organizational support: (Ridwan et al., 2020), (Djoko Setyo Widodo, P. Eddy Sanusi Silitonga, 2017), (Agussalim, Ayu Rezkiana Putri, et al., 2016).

6) Comunikation: (C.C. Widayati et al., 2020), (Christina Catur Widayati et al., 2020), (Ridwan et al., 2020), (Djoko Setyo Widodo, P. Eddy Sanusi Silitonga, 2017), (Agussalim, Ayu Rezkiana Putri, et al., 2016).

\section{CONCLUSIONS AND RECOMMENDATION}

\section{Conclusions}

Based on the theory, relevant articles and discussions, hypotheses can be formulated for further research:

1) Job involvement has an effect on employee job satisfaction.

2) Work involvement has an effect on organizational commitment.

3) Work involvement has an effect on employee performance.

4) Job satisfaction has an effect on employee performance.

5) Organizational commitment affects employee performance.

6) Job involvement through job satisfaction has an effect on employee performance.

7) Work involvement through organizational commitment affects employee performance.

\section{Recommendation}

Based on the conclusions above, the suggestion in this article is that there are many other factors that affect employee performance or employee performance at all types and levels of the organization, therefore further studies are needed to complement what other factors can affect Performance. Other factors such as work environment, motivation, work culture, leadership, perceived organizational support, and communication.

\section{Bibliography}

Abutayeh, B., \& Al-Qatawneh, M. (2012). The effect of human resource management practices on job involvement in selected private companies in Jordan. Canadian Social Science, $8(2)$.

Agussalim, M., Ayu Rezkiana Putri, M., \& Ali, H. (2016). Analysis work discipline and work spirit toward performance of employees (case study tax office Pratama two Padang). International Journal of Economic Research.

Agussalim, M., Kristin, M., \& Ali, H. (2016). Role of revolving loan program community national urban self (PNPM MP) against poverty prevention in Padang. International Journal of Applied Business and Economic Research.

Ali, H., Limakrisna, N., \& Jamaluddin, S. (2016). Model of customer satisfaction: The empirical study at Bri in Jambi. International Journal of Applied Business and Economic Research. 
Anwar Prabu, M. (2017). Manajemen Sumber Daya Manusia Perusahaan, Bandung: PT. In Remaja Rosdakarya.

Ariana, I., \& Riana, I. (2016). Pengaruh Work-Family Conflict, Keterlibatan Kerja Dan Stres Kerja Terhadap Kepuasan Kerja Karyawan. E-Jurnal Manajemen Universitas Udayana, 5(7), 255105.

Bastari, A., -, H., \& Ali, H. (2020). Determinant Service Performance Through Motivation Analysis And Transformational Leadership. International Journal of Psychosocial Rehabilitation. https://doi.org/10.37200/ijpr/v24i4/pr201108

Brata, Husani, Hapzi, B. H. S. A. (2017). Saudi Journal of Business and Management Studies Competitive Intelligence and Knowledge Management: An Analysis of the Literature. Saudi Journal of Business and Management Studies. https://doi.org/10.21276/sjbms

Chauhan, R., Ali, H., \& Munawar, N. A. (2019). Building Performance Service Through Transformational Leadership Analysis, Work Stress And Work Motivation (Empirical Case Study In Stationery Distributor Companies). Dinasti International Journal of Education Management And Social Science. https://doi.org/10.31933/dijemss.v1i1.42

Coulter, \& Robbins. (2012). Konsep Dasar Manajemen. E - Jurnal Riset Manajemen.

Damayanti, R., Hanafi, A., \& Cahyadi, A. (2018). Pengaruh Kepuasan Kerja Terhadap Kinerja Karyawan (Studi Kasus Karyawan Non Medis Rs Islam Siti Khadijah Palembang). JEMBATAN, 15(2). https://doi.org/10.29259/jmbt.v15i2.6655

Desfiandi, A., Desfiandi, A., \& Ali, H. (2017). Composite Stock Price Index (IHSG) Macro Factor in Investment in Stock (Equity Funds). International Journal of Economics and Financial Issues.

Deswarta. (2017). Pengaruh Kompetensi Dan Motivasi Terhadap Kepuasan Kerja Dan Kinerja Dosen Fakultas Tarbiyah Dan Keguruan Uin Sultan Syarif Kasim Riau. Jurnal Valuta, $3(1)$.

Djojo, A., \& Ali, H. (2012). Information technology service performance and client's relationship to increase banking image and its influence on deposits customer banks loyalty (A survey of Banking in Jambi). In Archives Des Sciences.

Djoko Setyo Widodo, P. Eddy Sanusi Silitonga, \& H. A. (2017). Organizational Performance: Analysis of Transformational Leadership Style and Organizational Learning. Saudi Journal of Humanities and Social Sciences. https://doi.org/10.21276/sjhss.2017.2.3.9

Elmi, F., Setyadi, A., Regiana, L., \& Ali, H. (2016). Effect of leadership style, organizational culture and emotional intelligence to learning organization: On the Human Resources Development Agency of Law and Human Rights, Ministry of Law and Human Rights. International Journal of Economic Research.

Fung, N. S., Ahmad, A., \& Omar, Z. (2014). Role of work-family enrichment in improving job satisfaction. American Journal of Applied Sciences, 11(1). https://doi.org/10.3844/ajassp.2014.96.104

Gibson, Ivancevich, D. (2010). Organisasi dan Manajemen : Perilaku, Struktur dan Proses. In Organizational Behavior.

Hakim, A. (2015). Effect of Organizational Culture, Organizational Commitment to Performance : Study In Hospital Of District South Konawe Of Southeast Sulawesi. The International Journal Of Engineering And Science, 4(5).

Handoko, T. H. (2011). Manajemen Personalia dan Sumber Daya Manusia. Pengantar Manajemen.

Hapzi Ali. Nandan Limakrisna. (2013). Metodologi Penelitian ( Petunjuk Praktis Untuk Pemecahan Masalah Bisnis, Penyusunan Skripsi, Tesis, dan Disertasi. In Deeppublish: Yogyakarta. 
Harini, S., Hamidah, Luddin, M. R., \& Ali, H. (2020). Analysis supply chain management factors of lecturer's turnover phenomenon. International Journal of Supply Chain Management.

Hasanah, N. (2014). Pengaruh Keterlibatan Kerja terhadap kepuasan kerja karyawan ditjen penyelenggara haji dan umrah kemenag RI. UIN Syarif Hidayatullah Jakarta.

Hasibuan, M. (2016). Manajemen Dasar Pengertian dan Masalah Edisi Ke-7. In Jakarta: Bumi Aksara.

Hiriyappa, B. (2009). Organizational Behavior. New Delhi: New Age International Publishers Ibrahim, M., Tewal, B., \& Taroreh, R.N. (2021). Pengaruh Work-Family Conflict dan Keterlibaran Kerja Melalui Kepuasan Kerja Terhadap Kinerja (Studi pada Dosen Wanita Fakultas Ekonomi dan Bisnis Unsrat). Jurnal EMBA, Vol. 9, No. 1.

Kembau, J.B., Sendow, G.M., dan Tawas, H.N. (2018). Pengaruh Keterlibatan Kerja dan Kompetensi Kerja Terhadap Kepuasan Kerja dan Kinerja Guru Sekolah Dasar di Kecamatan Malalayang Kota Manado. Jurnal EMBA, Vol. 6, No. 4.

Kreitner, R., \& Kinicki, A. (2014). Perilaku Organisasi Organizational Behavior. In 1.

Kusumastuti, I., ita Kurniawati, N., Loka Satria, D., \& Wicaksono, D. (2019). ANALISIS Pengaruh Lingkungan Kerja Terhadap Kinerja Karyawan Dimediasi Oleh Kepuasan Kerja Karyawan Pada Sp Alumunium Di Yogyakarta. Jurnal Riset Ekonomi Manajemen (REKOMEN), 3(1). https://doi.org/10.31002/rn.v3i1.1540

Logahan, J. M., \& Aesaria, S. M. (2014). Budaya Organisasi dan Keterlibatan Kerja terhadap Komitmen Organisasi Berdampak pada Kinerja Karyawan pada BTN - Ciputat. Binus Business Review, 5(2). https://doi.org/10.21512/bbr.v5i2.1026

Luthans, F. (2006). Perilaku Organisasi, Edisi Sepuluh. PT. Andi: Yogyakarta.

Masydzulhak, P. D., Ali, P. D. H., \& Anggraeni, L. D. (2016). The Influence of work Motivationand Job Satisfaction on Employee Performance and Organizational Commitment Satisfaction as an Intervening Variable in PT. Asian Isuzu Casting Center. In Journal of Research in Business and Management.

Munparidi, \& Sayuti, A. J. (2020). Pengaruh Keterlibatan Karyawan terhadap Kinerja Karyawan melalui Kepuasan Kerja sebagai Variabel Mediasi. Jurnal Aplikasi Manajemen Dan Bisnis, $1(1)$.

Nazir, O., \& Islam, J. U. (2017). Enhancing organizational commitment and employee performance through employee engagement: An empirical check. South Asian Journal of Business Studies. https://doi.org/10.1108/SAJBS-04-2016-0036

Paryati, A., Praningrum, A., \& Susetyo, S. (2019). Pengaruh Keterlibatan Kerja Terhadap Kinerja Pegawai Dengan Mediasi Komitmen Organisasi Pada Beberapa Kantor Dinas Di Kota Bengkulu. Managament Insight: Jurnal Ilmiah Manajemen, 13(1). https://doi.org/10.33369/insight.13.1.114-125

Pitaloka, E., \& Putri, F. M. (2021). The Impact of Employee Engagement and Organizational Commitment on Employee Performance. Business Management Journal, 17(2).

Prayetno, S., \& Ali, H. (2017). Analysis of advocates organizational commitment and advocates work motivation to advocates performance and its impact on performance advocates office. International Journal of Economic Research.

Prihartono, \& Ali, H. (2020). The promises ethics and marketing concept strategy as a competitive advantage on private higher education (A survey on perception of product attributes and promotion mix in Indonesia). Talent Development and Excellence.

Purba, C. B., Arzio, \& Ali, H. (2017). The influence of compensation, working environment and organization culture on working productivity of BPJS (workers social security agency) employment staff in Rawamangun Branch. Man in India.

Putranti, H. R. D., Megawati, M., \& Setyobudi, S. (2018). Pengaruh Budaya Kerja Dan 
Komitmen Organisasi Terhadap Kinerja Melalui Motode TULTA Sebagai Variabel Kontrol. Jurnal Inspirasi Bisnis Dan Manajemen, 2(2). https://doi.org/10.33603/jibm.v2i2.1556

Rameshkumar, M. (2020). Employee engagement as an antecedent of organizational commitment - A study on Indian seafaring officers. Asian Journal of Shipping and Logistics, 36(3). https://doi.org/10.1016/j.ajsl.2019.11.003

Rani, S., Agustiani, H., Ardiwinata, M. R., \& Purwono, R. U. (2020). Work Engagement and Organizational Commitment in Private University. https://doi.org/10.5220/0008590904640468

Ridwan, M., Mulyani, S. R., \& Ali, H. (2020). Building behavior and performance citizenship: Perceived organizational support and competence (case study at SPMI private university in west Sumatra). International Journal of Psychosocial Rehabilitation. https://doi.org/10.37200/IJPR/V24I6/PR260195

Rikmaratri, R. D. D., \& Prohimi, A. H. A. (2018). Dampak Keterlibatan Kerja Dan Dukungan Organisasi Terhadap Komitmen Organisasi. Ekonomi Bisnis, 23(1). https://doi.org/10.17977/um042v23i1p1-10

Rivai, A., Suharto, \& Ali, H. (2017). Organizational performance analysis: Loyalty predictors are mediated by work motivation at urban village in Bekasi City. International Journal of Economic Research.

Riyanto, S., Pratomo, A., \& Ali, H. (2017). Effect Of Compensation And Job Insecurity On Employee Engagement (Study On Employee Of Business Competition Supervisory Commission Secretariat). International Journal of Advanced Research. https://doi.org/10.21474/ijar01/4139

Riyanto, S., Sutrisno, A., \& Ali, H. (2017). International Review of Management and Marketing The Impact of Working Motivation and Working Environment on Employees Performance in Indonesia Stock Exchange. International Review of Management and Marketing.

Robbins, S., \& Judge. (2013). Perilaku Organisasi Edisi 16. In Jakarta: Salemba Empat.

Robbins, S. P. (1996). Organizational Behavior: Concepts, Controversies and Applications. In Development.

S, W., \& Susanto, H. A. (2018). Pengaruh Budaya Organisasi, Komitmen Organisasi dan Kepuasan Kerja Terhadap Kinerja Karyawan (Studi Pada PT. Bank Rakyat Indonesia (Persero) Tbk. Kantor Wilayah Semarang). Prosiding Sendi_u, ISBN: 978.

Sajdah, Q., \& Lukiyana. (2018). Pengaruh Keterlibatan Kerja Dan Dukungan Organisasi Yang Dirasakan Terhadap Kinerja Karyawan Yang Diintervening Oleh Kepuasan Kerja Pada Divisi Sdm Dan Keuangan Pt. Pelabuhan Tanjung Priok, Jakarta. Jurnal Online Internasional \& Nasional, 6(2), 45-56.

Sardjijo, S., \& Ali, H. (2017). Integrating Character Building into Mathematics and Science Courses in Elementary School. International Journal of Environmental and Science Education. https://doi.org/10.1007/s10648-016-9383-1

Sedarmayanti. (2017). Perencanaan Dan Pengembangan Sumber Daya Manusia Untuk Meningkatkan Kompetensi, Kinerja, Dan Produktivitas Kerja. In Perencanaan Dan Pengembangan Sumber Daya Manusia Untuk Meningkatkan Kompetensi, Kinerja, Dan Produktivitas Kerja.

Septiadi, S. A., Sintaasih, D. K., \& Wibawa, I. M. A. (2017). Pengaruh Keterlibatan Kerja Terhadap Kinerja Dengan Pemediasi Komitmen Organisasional. E-Jurnal Ekonomi Dan Bisnis Universitas Udayana. https://doi.org/10.24843/eeb.2017.v06.i08.p07

Silitonga, P. E. S., Widodo, D. S., \& Ali, H. (2017). Analysis of the effect of organizational commitment on organizational performance in mediation of job satisfaction (Study on Bekasi City Government). International Journal of Economic Research.

Sopiah. (2015). Perilaku Organisasional. Yogyakarta: Andi. 
Sulaeman, A. S., Waluyo, B., \& Ali, H. (2019). Making dual procurement and supply chain operations: Cases in the indonesian higher education. International Journal of Supply Chain Management.

Syamsuri, A. R. (2018). Analisis Budaya Kaizen dan Keterlibatan Kerja dengan Komitmen Organisasi sebagai Intervening terhadap Prestasi Kerja Karyawan (Studi Empiris pada PT. Gloria Jaya Sejahtera Medan). Jurnal Samudra Ekonomi Dan Bisnis, 9(2). https://doi.org/10.33059/jseb.v9i2.765

Tanjung, H. (2019). Pengruh Keterlibatan Kerja Dan Kepuasan Kerja Terhadap Komitmen Organisasi Pegawai. Jurnal Humaniora, 4(2).

Tentama, F., Rahmawati, P. A., \& Muhopilah, P. (2019). The effect and implications of work stress and workload on job satisfaction. International Journal of Scientific and Technology Research, 8(11).

Triatna, C. (2015). Perilaku Organisasi dalam Pendidikan. Bandung: Remaja Rosdakarya

Trofimov, A., Bondar, I., Trofimova, D., Miliutina, K., \& Riabchych, I. (2017). Organizational commitment factors: Role of employee work engagement. Espacios, 38(24).

van Gelderen, B. R., \& Bik, L. W. (2016). Affective organizational commitment, work engagement and service performance among police officers. Policing, 39(1). https://doi.org/10.1108/PIJPSM-10-2015-0123

Widayati, C.C., Ali, H., Permana, D., \& Nugroho, A. (2020). The role of destination image on visiting decisions through word of mouth in urban tourism in Yogyakarta. International Journal of Innovation, Creativity and Change, 12(3).

Widayati, Christina Catur, Ali, H., Permana, D., \& Nugroho, A. (2020). The role of destination image on visiting decisions through word of mouth in urban tourism in Yogyakarta. International Journal of Innovation, Creativity and Change.

Wuarlima, F., Kojo, C., \& Sendow, G.M. (2019). Pengaruh Keseimbangan Kehidupan Kerja, Keterlibatan Kerja dan Pengembangan Karir Terhadap Kepuasan Kerja Karyawan pada Grand Puri Hotel Manado. Jurnal EMBA, Vol. 7, No. 4.

Yakup, Y. (2017). Pengaruh Keterlibatan Kerja, Budaya Organisasi dan Motivasi Kerja terhadap Kepuasan Kerja Pegawai. Perisai : Islamic Banking and Finance Journal, 1(3), 273-290. https://doi.org/10.21070/perisai.v1i3.1112 